\title{
Does Integrated Information Systems have an Impact on Implementation of Accrual Basis Accounting and Fiscal Transparency?
}

\author{
Donny Maha Putra, Moermahadi Soerja Djanegara, Sri Mulyani, Sudarto, Citra Sukmadilaga
}

\begin{abstract}
The Implementation of accrual basis as a public policy must be supported by information technology and systems that are integrated. This study discusses the increasing use of integrated information systems on the implementation of accrual basis and improving the quality of government financial transparency. The research data were collected using questionnaire instruments, face-to-face interviews and discussion group activities through surveys conducted at 85 Line Ministries in Indonesia. The research data was analysed using CB-SEM with the help of Lisrel 8.8 statistical software. The research findings prove that information systems are integrated significantly towards the implementation of the accrual basis and improving the quality of government approval.
\end{abstract}

Index Terms: Integrated Information Systems, Accrual Accounting, Fiscal Tranparency, Government, Indonesia

\section{INTRODUCTION}

Many factors influence the implementation of the accrual basis to public sector accounting. According to Spathis and Constantinides [31], accrual basis implementation requires information system integration in integrating accounting processes properly. The use of integrated information systems can provide great motivation for staff, able to increase the efficiency of resource use, and automate data collection and processing [33]. This opinion is supported by Mulyani, Anugrah and Hassan [23] that information systems can improve efficiency, improve process effectiveness, improve internal control structures and make decision making better. Accrual implementation requires information system integration support in consolidating at least 26,985 financial statements of government accounting entities [4].

According to Waisapy [34], accrual practices are believed to be able to provide better information on government performance so that they can improve the quality of government fiscal transparency. Fiscal transparency is a comprehensive, transparent, reliable, timely and relevant government financial reporting on the state of government finances [20]. Good fiscal transparency is demonstrated through increasing the role of the public financial reporting system as a critical component of international financial architecture ([3]; [5]; [9]).

Revised Manuscript Received on August 05, 2019. Finance of Indonesia. (Email:donnymp@kemenkeu.go.id)

Moermahadi Soerja Djanegara, Indonesian Supreme Audit Institution, Indonesia. (Email: moermahadi2001@yahoo.com)

Sri Mulyani, Faculty of Economics and Business,Universitas Padjadjaran, Indonesia (Email:sri.mulyani@unpad.ac.id,)

Sudarto,Directorate General of Treasury, Ministry of Finance of Indonesia. (Email:sudarto@kemenkeu.go.id)

Citra Sukmadilaga, Faculty of Economics and Business,Universitas Padjadjaran, Indonesia (Email:citra.sukmadilaga@unpad.ac.id)
Donny Maha Putra, Directorate General of Treasury, Ministry of

The practice of accruals in the Indonesian government still leaves many problems. 2015, Supreme Audit Institution (BPK) audit still found tens of thousands of problems in applying the accrual basis to the entity. The problem is because the application system has not been fully integrated [4]. According to the BPK [4] governance, development, and implementation, as well as the operationalisation of information system technology have not been fully effective in supporting good financial reporting. The Ministry of Finance does not yet have a strategic plan, development and operationalisation of cross-institutional information systems that support central government financial reporting. The application user does not provide an automatic mechanism to compare the final balance data per entity.

Sukmadilaga, Pratama and Mulyani [32] revealed that the level of disclosure as one of the indicators of government fiscal transparency is still low, so efforts need to be made to improve it. The lack of optimal government fiscal transparency is also shown by the IBP study [14] which states that the level of the Indonesian government's fiscal transparency related to budget disclosure is still not right. This is because the Indonesian government is still limited in presenting budget information to the public.

The empirical facts above show that there are still problems related to the information system used by the Indonesian government in the implementation of the accrual basis and certainly have an impact on the quality of government fiscal transparency. While the previous literature ([31];[33];[23]) explains that integrated information systems can implement the accrual basis better. Thus the question arises: (1) is the information system capable of providing an impact on the implementation of the accrual basis and fiscal transparency? (2) How significant is the influence of the integrated information system? Moreover, (3) how to measure it? Although there is much research on the implementation of the accrual basis to public sector accounting, it has not been able to answer this research question.

Some previous literature focused more on the benefits and uses of accrual basis ([22]; [26]), barriers and challenges in implementation [12] readiness for application [2], and implementation strategies [24]. Thus this research is essential to answer the research question by testing how much influence the use of integrated information systems on the implementation of accrual basis and improving the quality of fiscal transparency. The results of this study are believed to be able to provide academic recommendations in 
preparing policy strategies for accrual implementation to be able to answer the problems that have still been faced by the Indonesian government.

\section{LITERATURE REVIEW}

\section{A. Use of Integrated Information Systems}

The integrated information system is a collection of several collections of information that are combined in an organised manner, collected at different times by different units to be available to all who need it [30]. The integrated information system is a mechanism to describe the relationship of information technology in organisations that are separate from standardised business processes ([21]; [13]). Thus, the use of integrated information systems is defined in the context of this research as the integration of application and information systems in Ministries and Institutions with information systems at the Ministry of Finance in the context of managing state finances to produce transparent and accountable government financial information.

The effect of using integrated information systems on the application of accrual accounting and improving the quality of fiscal transparency in this study was measured using 10 indicators ([21]; [18]), namely: database integration; standard in data definition; communication networks connectivity; communication networks flexibility; compatibility integration; ergonomic integration; horizontal integration; vertical integration; intra-organization integration and inter-organization integration.

\section{B. Implementation of Accrual Basis}

Accrual accounting is defined as data entry made at the end of the accounting period to reflect events that have occurred, but cash or cash equivalents have not been received or disbursed ([36];[28]). Accrual accounting is not just recording cash receipts and expenses. However, recognition of income, costs, profits, losses, and the addition or decrease of assets and liabilities includes matching between costs and revenues, allocations, and amortisation ([35]; [11]). Khan and Mayes [16] define accrual accounting as an accounting methodology where transactions are recognised as economic events that underlie records, regardless of the time cash receipts, and payments occur. Accrual-based government accounting implementation in this study is defined as the implementation of accounting practices based on the recognition of the occurrence of transactions in accounting entities in Line Ministries in preparing government financial reports.

The effect of the application of accrual accounting on improving the quality of fiscal transparency in this study was measured using 13 indicators ([16]; [27]; [6]), namely: adapting existing financial rules and regulations; documenting accounting policies; developing comprehensive guidance and manuals; managing the transition period and monitoring; checking data quality during the reform process; designing quality control procedures for setting up data collection procedures; ensuring compliance with existing regulatory framework; inspiring change of mentalities and cultural change; ensuring political commitment; increasing staff and public awareness; building up public sector accountants expertise; developing training programs and allowing knowledge transfer; adapting existing IT systems; and/or developing new IT solutions; and translating organizational processes into the IT environment.

\section{Improving the Quality of Government Fiscal} Transparency

Fiscal Transparency is comprehensive, precise, reliable, timely, and relevant government reporting on past, present, and future government financial conditions ([25]; [20]). Cottarelli [8] defines fiscal transparency as clarity, reliability, frequency, timeliness, and relevance of state financial management reporting and openness to the public in the government's fiscal policy-making process.

Thus the quality of fiscal transparency in this study is defined as the quality of information on state financial management that is presented in a comprehensive, transparent, reliable, timely and relevant manner. The quality of fiscal transparency in this study was measured using 11 indicators [15] namely coverage; frequency and timeliness; quality; integrity; comprehensiveness; orderliness; policy orientation; credibility; risk disclosure and analysis; risk management; and fiscal coordination.

\section{Research Hypothesis}

The use of integrated information systems guarantees the coherence of the accounting model with accrual principles through accounting records needed for management control [31]. Integrated information systems have a positive influence on the implementation of accrual accounting with its functionality to increase accruals of discretion [16]. Integrated information systems are the main factors that influence the implementation of accrual accounting [33]. Thus the researcher hypothesised:

H1: The use of integrated information systems has a positive effect on the implementation of accrual-based government accounting standards (SAP).

Integrated information systems are designed to improve the system of recording, tracking, and managing financial data so that transparency and fiscal accountability in the process of financial management in the public sector improve [19]. According to Selfano et al. [29], integrated information systems have a positive influence in improving transparency in government financial management, increasing the trust and credibility of the budget through the completeness and transparency of the financial information presented. Chado [7] explained that integrated information systems provide positive benefits in fiscal management to be better, increase fiscal transparency and accountability, and make government transaction costs lower. Thus the researcher hypothesised:

H2: The use of integrated information systems has a positive effect on improving the quality of government fiscal transparency.

According to FEE [10], information disclosure of the government using an accrual basis is beneficial for investors. Lampe, Hilgers and Ihl [17] explain that the 
implementation of accrual accounting has a positive influence in improving fiscal transparency because it can provide a good view of government finance, assets and budget risk. The implementation of accrual-based accounting standards has a positive impact in encouraging transparency and accountability of financial information in providing information on government financial management ([1];[16]). Thus the researcher hypothesised:

H3: The accrual basis application has a positive effect on improving the quality of government fiscal transparency.

\section{RESEARCH METHODS}

This study uses descriptive and causal-explanatory methods by testing the research hypothesis. In this study, researchers attempted to explain the cause or effect relationship of the use of integrated information systems on the accrual basis implementation and improving the quality of fiscal transparency. The population in this study were 85 Line Ministries. The sample in this study was designed using a non-probability sampling method with a census technique approach. The unit of analysis in this study is the consolidated working unit which prepares Line Ministries financial statements.

The observation unit in this study is the Budget User Accounting Unit and the Goods User Accounting Unit in the consolidated working unit at the Line Ministries level. While the respondents in this study were the head of the bureau/head of finance/head of the accounting sub-section, and the implementing staff/SIMAK-BMNoperators/SAIBA operators who were directly involved in the process of preparing financial reports at the Line Ministry level. Data analysis in this study uses quantitative methods through descriptive analysis to explain the profile of respondents and analyse the responses of respondents through the scoring process of the answers of each respondent. Verification analysis in this study uses the Structural Equation Modeling (SEM) approach by testing the measurement model and testing the structural model of the study.

\section{RESEARCH FINDINGS}

The research survey was conducted for four months and 17 days by visiting the analysis unit, namely the consolidated working unit as the unit that prepared financial reports at the level of Line Ministries. Data collected through questionnaires in this study were 149 respondents in 85 Line Ministries (97.70\% population) and through face-toface interviews with 77 experts in 77 Line Ministries (88.51\% of the population). The data collected is complemented by data obtained through Forum Group Discussion activities carried out in five Line Ministries. The results of testing the latent variable measurement model show that all dimensions and indicators have a standard factor loading (SFL) value greater than 0.5.

The value of construct reliability (CR) is more significant than 0.7 , and the value of variance extracted (VE) is more significant than 0.5 . This means that all indicators of each variable are declared valid and reliable in measuring each variable in this study. The estimation of the structural model in this study uses the latent variable score. The results of hypothesis testing are shown in Figure 1, and the magnitude of the influence between variables is shown in Figure 2. The evaluation results of the essential goodness of fit prove that the model in this study is to fit with the data.

The results of testing the suitability of the research model are shown in Table 1. The results of testing the goodness of fit statistics shown in Table 1 conclude that the value of NFI, NNFI, CFI, IFI, RFI, GFI, AGFI $\geq 0.90$ and the value of RMSEA $=0.003 \leq 0.08$ means that the model fit is good. While the value of $\mathrm{SRMR}=0.088 \geq 0.05$ indicates that the suitability of the model is not good (not fit). The p-value = $0.99973 \geq 0.05$ indicates a very good level of compatibility. Based on a combination of various measures of compatibility of the model, it can be concluded that the model in this study as a whole has an excellent level of compatibility of the model

Table 1. Research Model Good-Fit Test Results

\begin{tabular}{|l|l|l|l|l|}
\hline No & $\begin{array}{l}\text { GOF } \\
\text { Index }\end{array}$ & Cut Point & Value & Results \\
\hline 1 & Chi-square & $\begin{array}{l}\text { p-value } \\
0.05\end{array}$ & 0.99973 & $\begin{array}{l}\text { Good } \\
\text { Fit }\end{array}$ \\
\hline 2 & RMSEA & $\begin{array}{l}\text { RMSEA } \\
0.08\end{array}$ & 0.003 & $\begin{array}{l}\text { Good } \\
\text { Fit }\end{array}$ \\
\hline 3 & NFI & NFI $\geq 0.90$ & 0.93 & $\begin{array}{l}\text { Good } \\
\text { Fit }\end{array}$ \\
\hline 4 & NNFI & NNFI $\geq 0.90$ & 0.99 & $\begin{array}{l}\text { Good } \\
\text { Fit }\end{array}$ \\
\hline 5 & CFI & CFI $\geq 0.90$ & 0.99 & $\begin{array}{l}\text { Good } \\
\text { Fit }\end{array}$ \\
\hline 6 & IFI & IFI $\geq 0.90$ & 0.99 & $\begin{array}{l}\text { Good } \\
\text { Fit }\end{array}$ \\
\hline 7 & RFI & RFI $\geq 0.90$ & 0.93 & $\begin{array}{l}\text { Good } \\
\text { Fit }\end{array}$ \\
\hline 8 & SRMR & SRMR $\leq 0.05$ & 0.088 & Not Fit \\
\hline 9 & GFI & GFI $\geq 0.90$ & 0.94 & $\begin{array}{l}\text { Good } \\
\text { Fit }\end{array}$ \\
\hline 10 & AGFI & AGFI $\geq 0.90$ & 0.95 & $\begin{array}{l}\text { Good } \\
\text { Fit }\end{array}$ \\
\hline
\end{tabular}

After the model is declared suitable, then the next hypothesis is tested to determine the value of the causal relationship between variables. The measurement results are shown in Table 2. 
Does Integrated Information Systems have an Impact on Implementation of Accrual Basis Accounting and Fiscal Transparency?

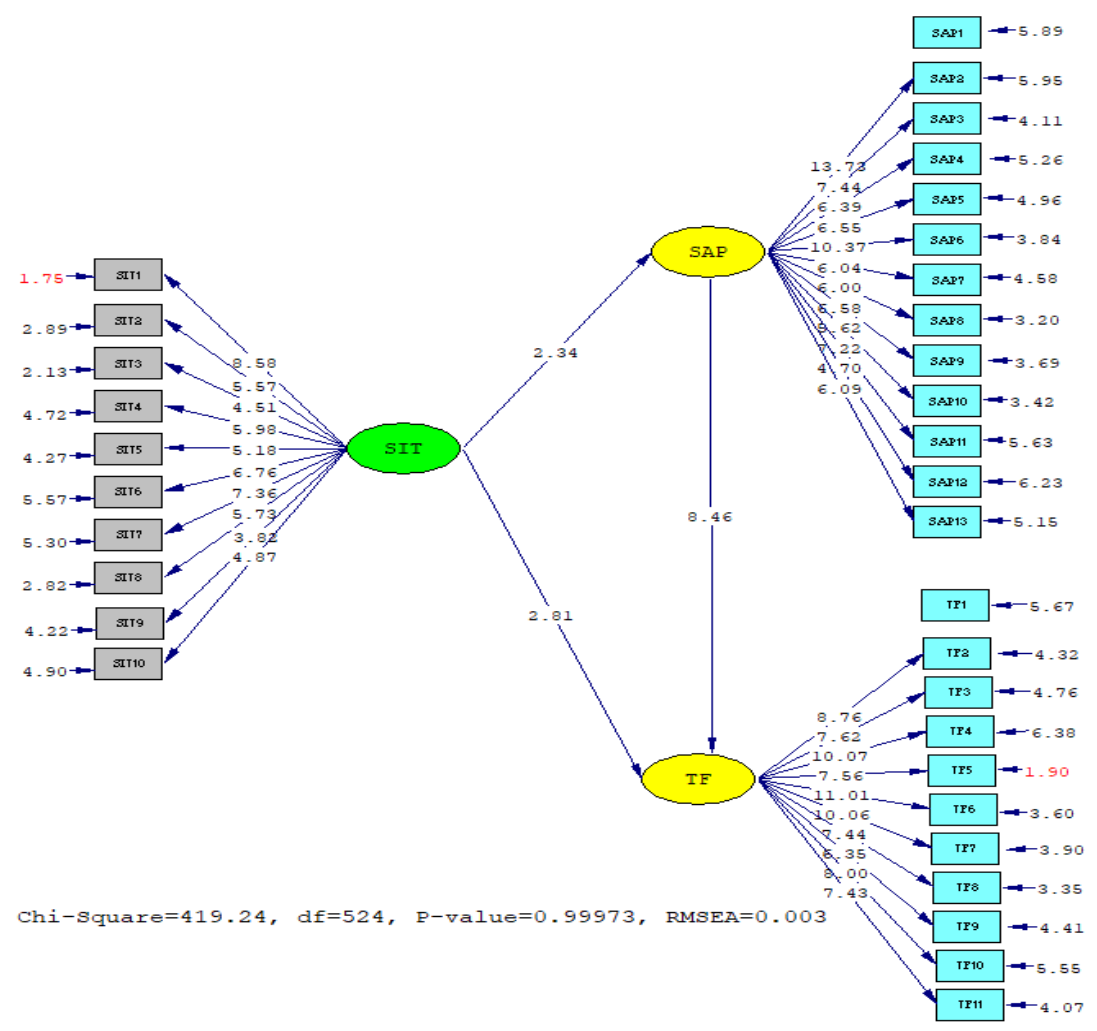

Figure 1. Testing of Research Hypotheses

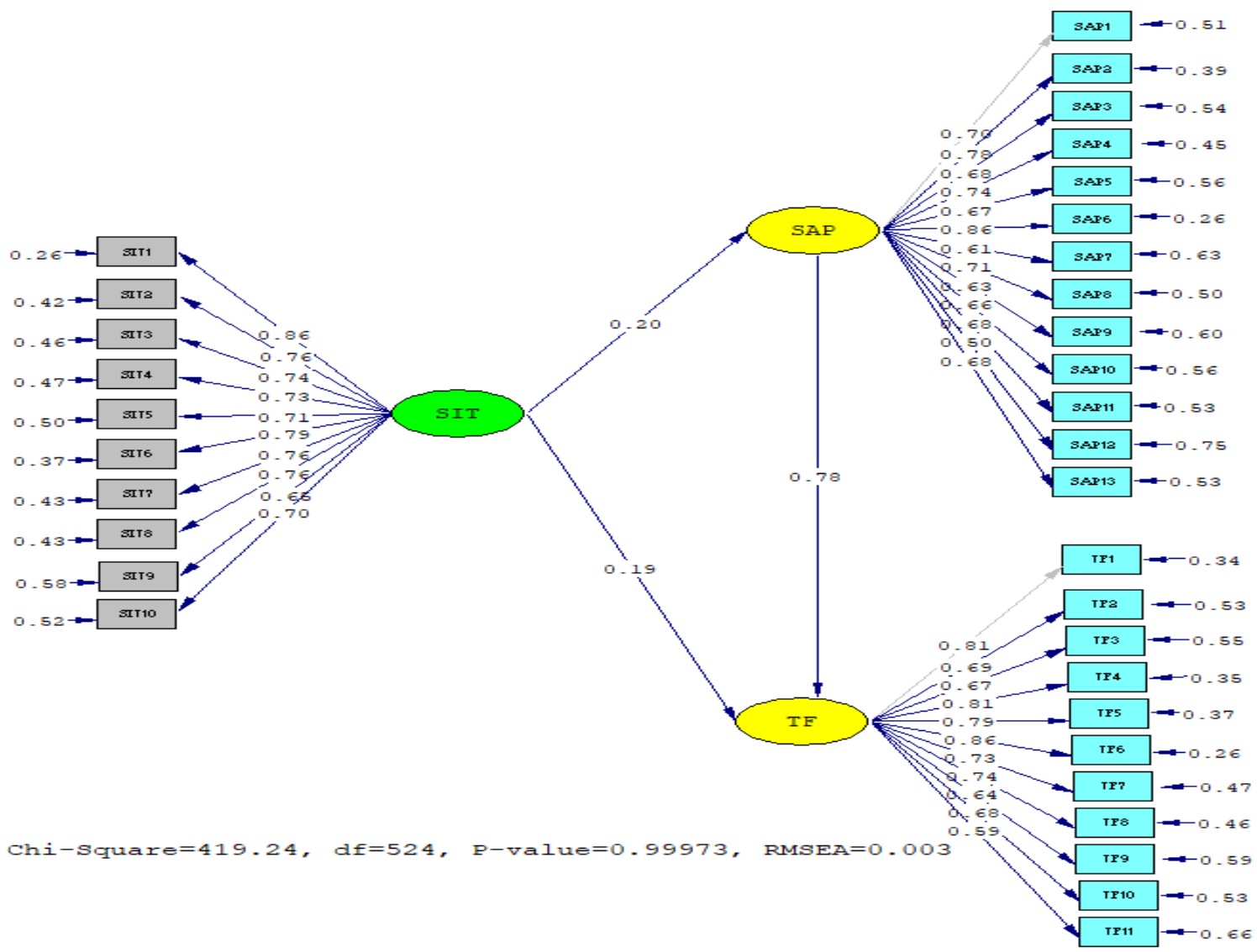

Figure 2. Estimates of Inter-Variable Relations

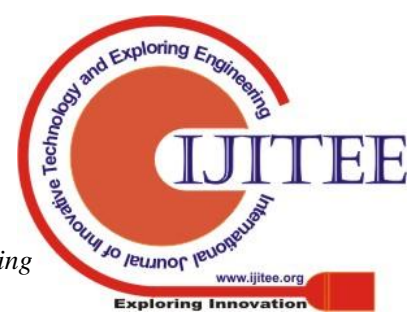


The results of the statistical hypothesis testing shown in Table 2 aim to ensure there are no differences in the results between the data in the sample and the population. The statistical hypothesis testing in this study is explained as follows.

The effect of using integrated information systems on the accrual basisimplementation.

$\mathrm{H}_{0}: \gamma_{11} \leq 0$ The use of integrated information systems does not have a positive effect on the accrual basis implementation

$\mathrm{H}_{1}: \gamma_{11}>0 \quad$ The use of integrated information systems does have a positive effect on the accrual basis implementation

The effect of the use of integrated information systems on improving the quality of fiscal transparency.

$\mathrm{H}_{0}: \gamma_{12} \leq 0$ The use of integrated information systems does not have a positive effect on improving the quality of fiscal transparency.

H1 $: \gamma 12>0$ The use of integrated information systems does have a positive effect on improving the quality of fiscal transparency.

The effect of accrual basis implementation on improving the quality of fiscal transparency.
$\mathrm{H}_{0}: \beta_{21} \leq 0$
Accrual basis implementation does not have a positive effect on improving the quality of fiscal transparency.
H1: $\beta_{21}>0 \quad$ Accrual basis implementation have a positive effect on improving the quality of fiscal transparency.

Table 2. Results of Testing Research Hypotheses

\begin{tabular}{|l|l|l|l|l|}
\hline Hypotheses & Path & $\begin{array}{l}\text { t- } \\
\text { value } \\
(\geq 1,64 \\
)\end{array}$ & $\begin{array}{l}\text { Impact } \\
\text { Level }\end{array}$ & Conclusions \\
\hline $\mathrm{H}_{1}$ & $\begin{array}{l}\text { SIT -> } \\
\text { SAP }\end{array}$ & 2,34 & $20 \%$ & Rejected $\mathrm{H}_{0}$ \\
\hline $\mathrm{H}_{2}$ & $\begin{array}{l}\text { SIT -> } \\
\text { TF }\end{array}$ & 2,81 & $19 \%$ & Rejected $\mathrm{H}_{0}$ \\
\hline $\mathrm{H}_{3}$ & $\begin{array}{l}\text { SAP - } \\
>\text { TF }\end{array}$ & 8.46 & $78 \%$ & Rejected $\mathrm{H}_{0}$ \\
\hline
\end{tabular}

\section{DISCUSSION\& RESULTS}

This section discusses the results of testing the research hypothesis. Discussion of research findings is explained from the results of descriptive analysis and verification analysis which are then compared with the theory and results of previous studies

\section{A. Hypothesis 1}

systems has a positive effect of $20 \%$ on the accrual basis implementation. The influence is in the form of full integration of the information system used. Although currently, the information system used by Line Ministries is useful in the reporting consolidation process, it has not been integrated into a single database system so that accrual information cannot be presented in real time and is still periodic.
The findings of this study prove the Tanjeh study [33] that the use of integrated information systems can provide great motivation for staff, able to increase the efficiency of resource use, and automate data collection and processing. This finding is an input to the Ministry of Finance to immediately implement an application system with the concept of a single database system and integrated into a solution to the existing problems. The integrated system can integrate goods management and money management in a single centralised database system and fully integrated with the system at the Ministry of Finance.

\section{B. Hypothesis 2}

Based on the results of hypothesis testing shows that the use of integrated information systems has a positive effect of $19 \%$ on improving the quality of fiscal transparency. The influence is in the form of a financial information system that can present information optimally, especially regarding the absorption of the budget and the achievement of monthly revenue targets that can be accessed by the public as one of the indicators of fiscal transparency in real time. Information on the absorption of the budget and the achievement of the intended target is only for Line Ministries internal consumption and has not been published periodically to the public. So that it has not had a significant impact on the quality of government financial information presentation.

Based on the results of interviews with management, whether or not the quality of fiscal transparency is very much determined by the presentation of government financial information to the public. This can only be done if technology and information systems support the government in optimally presenting financial information. The findings of this study prove the study ([19];[7]) which concluded that integrated information systems could improve fiscal transparency and accountability so that government transaction costs are lower.

\section{Hypothesis 3}

The results of hypothesis testing show that the implementation of the accrual basis has a positive effect of $78 \%$ on improving the quality of government fiscal transparency. The results of this study support the study of Lampe et al. [17] which concluded that the application of accrual basis had a positive influence in improving the government's fiscal transparency. This finding also supports the study of Ahmad et al. [1] that the application of accrual bases in the public sector can provide positive benefits to fiscal transparency in the form of ease of obtaining access to accurate information as a responsibility of the government.

The research findings show that there are still several indicators that have not been optimal in the accrual basis implementation, including (1) Not yet 100\% Line Ministries has a technical guideline for implementing accrual accounting as a guideline for accrual implementation in Line Ministries entities. (2) The examining apparatus is not maximal in carrying out the process of analysing financial statements conducted in parallel with the process of implementing financial statements. (3) The examining 
apparatus has not maximally reviewed the financial statements because the reviews conducted are more administrative than substantive. (4) Information technology facilities and infrastructure are inadequate in preparing financial reports and cannot be integrated with applications provided by the Ministry of Finance.

\section{CONCLUSION}

The application of accrual basis to Line Ministries in Indonesia as the application of public policy only reached the output level. This means that the implementation of the accrual basis is limited to ensuring that all records of transactions are by the required accrual standards.

The use of integrated information systems has a significant effect on accrual basis implementation. The influence is in the form of full integration of the information system used so that it can present government accrual information in real time. Meanwhile, the use of integrated information systems has a significant effect on improving the quality of fiscal transparency. The influence is in the form of information system support that is integrated throughout the entity units to be able to provide data and information in a complete and timely manner.

Finally, the accrual basis can provide a significant favourable influence on improving the quality of fiscal transparency - this influence in terms of the availability of the latest reliable information technology facilities. The research findings recommend that the government immediately implement a fully integrated information system throughout the entity in Line Ministries. This system expected to be able to integrate the goods and money management in a single database system that is fully integrated with the system at the Ministry of Finance.

\section{REFERENCES}

1. Ahmad, N. N., Mazlan, S. N., Ahmad, S. D., \& Pangat, M. H. (2015) Challenges of Accrual Accounting Implementation In Malaysian Economics and Law, Vol. 8, Issue 1, 113-117.

2. Azmi, A. H. and Mohamed, N. (2014), "Readiness of Malaysian Public Sector Employees in Moving towards Accrual Accounting for Improve Accountability: The Case of Ministry of Education (MOE)", Procedia - Social and Behavioral Sciences, volume 164, pp.106-111, DOI:10.1016/j.sbspro.2014.11.057.

3. Becker, S. D., Jagalla, T., \& Skærbæk, P. (2014). The translation of accrual accounting and budgeting and the reconfiguration of public sector accountants' identities. Accounting, 25 (4-5), 324-338.

4. BPK. (2016). Ikhtisar Hasil Pemeriksaan Semester I Tahun 2016. Jakarta: Badan Pemeriksaan Keuangan RI.

5. Caramanis, C., Dedoulis, E., \& Leventis, S. (2015). Transplanting Anglo-American accounting oversight boards to a diverse institutional context. Accounting, Organizations and Society, 42, 12-31.

6. Cavanagh, J., Flynn, S., \& Moretti, D. (2016). Implementing Accrual Accounting in the Public Sector. International Monetary Fund Fiscal Affairs Department.

7. Chado, H. (2015). The Effect of Integrated Financial Management Information System on The Financial Management of Public Sector In Kenya. Nairobi: University of Nairobi.

8. Cottarelli, C. (2012). Fiscal Transparency, Accountability, and Risk. Fiscal Affairs Department.

9. Dedoulis, E. (2016). Institutional formations and the AngloAmericanization of local auditing practices The case of Greece. Accounting Forum, 40, 29-44.

10. FEE. (2016). Accrual accounting: a key step toward better public finances. d'Auderghem: Federation of European Accountants.

11. Gnanarajah, R. (2014). Cash Versus Accrual Basis of Accounting : An Introduction. Congressional Research Service. Accountant General's Department . International Journal of Business,

12. Harun, H. and Robinson, P. (2010), "The Adoption of Accrual Accounting in the Indonesian Public Sector", Research in Accounting in Emerging Economies, Volume 10, pp.233 - 250, DOI:10.1108/S1479-3563(2010)000001004.

13. Hedman, J., \& Sarker, S. (2015). Information system integration in mergers and acquisitions: research ahead. European Journal of Information Systems Volume 24, 117-120.

14. IBP. (2016, Desember). International Budget Partnership. Diambil kembali dari http://www.internationalbudget.org/openingbudgets/open-budget-initiative/open-budget-survey/countryinfo/?country=id.

15. IMF. (2014). The Fiscal Transparency Code. International Monetary Fund.

16. Khan, A., \& Mayes, S. (2009). Transition to Accrual Accounting. International Monetary Fund Fiscal Affairs Department.

17. Lampe, H. W., Hilgers, D., \& Ihl, C. (2015). Does accrual accounting improve municipalities' efficiency?. Evidence from Germany. Applied Economics, 1-15.

18. Mancini, D., \& Lamboglia, R. (2017). Accounting Information System and Transparency: A Theoretical Framework. Dalam K. Corsi, N. G. Castellano, R. Lamboglia, \& D. Mancini, Reshaping Accounting and Management Control Systems : New Opportunities from Business Information System (hal. 249-261). Cham, Switzerland: Springer International Publishing.

19. Mburu, M. M., \& Ngahu, S. (2016). Influence of Integrated Financial Management. International Journal of Economics, Commerce and Management, Vol. IV, Issue 5, 777-793.

20. Mijatovic, B. (2015). Fiscal Transparency Principles and Practice in Serbia. Southeast Europe Leadership for Development and Integrity.

21. Mohamed, N., Mahadi, B., Miskon, S., Haghshenas, H., \& Adnan, H. M. (2013). Information System Integration: A Review of Literature and a Case Analysis. Mathematics and Computers in Contemporary Science, 68-77.

22. Monteiro, B. R. and Gomes, R. C. (2013), "International experiences with accrual budgeting in the public sector" Revista Contabilidade \& Finanças, Volume. 24 No. 62, pp. 103-112, DOI:10.1590/S151970772013000200002.

23. Mulyani, S., Anugrah, F., \& Hassan, R. (2016). The critical Success Factors for The Use of Information Systems and Its Impact on The Organizational Performance. 2016. International Business Management Journal. Vol. 10. Number. 4., 552-560.

24. Pamungkas, Bambang. (2018). Accrual-Based Accounting Implementation In Indonesian's Local Governments Compared To Other Countries' Experiences. Man In India, 98 (1), pp. 1-23.

25. Poljašević, J., \& Radisavljević, D. V. (2014). Improving Government Financial Reporting in Order To Increase The Transparency and Efficiency of Public Service Delivery. Journal of International Scientific Publications, Economy \& Business Volume 8, 611-626.

26. PwC. (2013). Towards a new era in government accounting and reporting. Penerbit : PwC Firms.

27. PwC. (2014). Collection of information related to the potential impact, including costs, of implementing accrual accounting in the public sector and technical analysis of the suitability of individual IPSAS standards. Penerbit :PwC Firms.

28. Romney, M. B., \& Steinbart, P. J. (2015). Accounting Information System, Edition 13. New Jersey: Pearson Education, Inc.

29. Selfano, O. F., Peninah, A., \& Sarah, C. (2014). Integrated Financial Management Information System and Its Effect on Cash Management in Eldoret West District Treasury, Kenya. International Journal of Business and Social Science Vol. 5, No. 8, 31-37.

30. Shugarman, L. R., \& Zawadski, R. (2005). Integrated Information Systems Third Edition. Dalam C. J. Evashwick, The Continuum of Long-Term Care (hal. 216). Clifton Park, New York: Thomson Delmar Learning.

31. Spathis, C., \& Constantinides, S. (2004). Enterprise resource planning systems' impact on. Business Process Management Journal Vol. 10 No. 2, $234-247$.

32. Sukmadilaga, C., Pratama, A., \& Mulyani, S. (2015). Good Governance Implementation In Public Sector: Exploratory Analysis of Government Financial Statements Disclosures Across ASEAN Countries. Social and Behavioral Sciences 211 (hal. 513-518). Bali: Elsevier.

33. Tanjeh, M. S. (2016). Factors Influencing the Acceptance of International Public Sector Accounting Standards in Cameroon. Accounting and Finance Research Vol. 5, No. 2, 71-83. 
34. Waisapy, M. J. (2015). Kemkeu: Implementasi Akuntansi Akrual Siap Dijalankan. Jakarta: Berita Satu.

35. Warren, C. S., Reeve, J. M., \& Duchac, J. E. (2014). Accounting 25e. Mason, $\mathrm{OH}$ : South-Western, Cengage Learning.

36. Weygandt, J. J., Kimmel, P. D., \& Kieso, D. E. (2012). Accounting Principles Edition 10. Danvers, MA: John Wiley \& Sons, Inc. 